\section{Biochemical Requirements for Singlet Oxygen Production by Purified Human Myeloperoxidase}

\author{
Jeffrey R. Kanofsky, Jonathan Wright, \\ G. Elaine Miles-Richardson, and Alfred I. Tauber \\ Departments of Medicine, Edward Hines, Jr. VA Hospital, \\ Hines, Illinois 60141; Loyola University, Stritch School of \\ Medicine, Maywood, Illinois 60153; The William B. Castle \\ Hematology Research Laboratory, Boston City Hospital; and \\ Departments of Medicine and Biochemistry, Boston University \\ School of Medicine, Boston, Massachusetts 02118
}

duce ${ }^{1} \mathrm{O}_{2}$, the conditions required are not physiologic, which suggests that the chemiluminescence of the stimulated neutrophil does not derive from ${ }^{1} \mathrm{O}_{2}$ generated by a MPO mechanism.

\section{Introduction}

The human neutrophil exhibits a nonmitochondrial respiratory burst upon stimulation with either soluble agonists (e.g., phorbol myristate acetate) or phagocytosable particles. (1-3). The products of this burst are reduction products of molecular oxygen, including superoxide, its dismutation product, hydrogen peroxide $\left(\mathrm{H}_{2} \mathrm{O}_{2}\right)$, and hydroxyl radical, or species with like reactivity (1-3). The microbicidal capacity and deleterious toxicity to host tissue of the oxidizing system of $\mathrm{H}_{2} \mathrm{O}_{2}$, halide, and the lysosomal enzyme, myeloperoxidase (MPO), ${ }^{1}$ have been extensively characterized $(4,5)$. Recent reports have emphasized that hypochlorous acid $(\mathrm{HOCl})$ is an oxidizing mediator of this system (6-9), but whether another reactive species, singlet oxygen $\left({ }^{1} \mathrm{O}_{2}\right)$, is also a mediator of the phagocyte's microbicidal and cytotoxic properties is unsettled $(2,10,11)$. While there are hypothetical MPO-independent mechanisms for ${ }^{1} \mathrm{O}_{2}$ formation in the respiratory burst of the human neutrophil (12), the MPO- $\mathrm{H}_{2} \mathrm{O}_{2}$-chloride ion $\left(\mathrm{Cl}^{-}\right)$system is the most likely source of any ${ }^{1} \mathrm{O}_{2}$ that is generated by stimulated neutrophils $(13,14)$. However, the question of ${ }^{1} \mathrm{O}_{2}$ production by neutrophils or by the MPO- $\mathrm{H}_{2} \mathrm{O}_{2}-\mathrm{Cl}^{-}$system is still unresolved, because the methods used in previous studies could not distinguish between ${ }^{1} \mathrm{O}_{2}$ and other oxidizing species (15-18). In particular, ${ }^{1} \mathrm{O}_{2}$ traps and quenchers used in those studies have been shown to react with $\mathrm{HOCl}$ or $\mathrm{Cl}_{2}$. The most convincing negative study for ${ }^{1} \mathrm{O}_{2}$ production was that of Foote et al. (19) using the specific ${ }^{1} \mathrm{O}_{2}$ trap, cholesterol.

Attempts to demonstrate ${ }^{1} \mathrm{O}_{2}$ production by searching for

1. Abbreviations used in this paper: CPO, chloroperoxidase; LPO, lactoperoxidase; MPO, myeloperoxidase; ${ }^{1} \mathrm{O}_{2}$, singlet oxygen. 
its emission at 634 and $703 \mathrm{~nm}$ have been unsuccessful because the low intensity of any ${ }^{1} \mathrm{O}_{2}$ emission present is obscured by chemiluminescence from other sources $(16,20)$. The emission band at $1,268 \mathrm{~nm}$, however, is directly proportional to the ${ }^{\prime} \mathrm{O}_{2}$ concentration (21). At the low concentrations of ${ }^{1} \mathrm{O}_{2}$ potentially present in the human neutrophil, the $1,268-\mathrm{nm}$ band would be several orders of magnitude more intense than the dimole bands (17). Using newly developed infrared spectrophotometers that are highly sensitive to $1,268-\mathrm{nm}$ radiation, efficient ${ }^{1} \mathrm{O}_{2}$ production by lactoperoxidase (LPO) and chloroperoxidase (CPO) has recently been reported (22-25). Emission at this wavelength appears to be a sensitive and specific test for ${ }^{~} \mathrm{O}_{2}$. We have now applied this methodology to determine if ${ }^{1} \mathrm{O}_{2}$ is produced by a purified human MPO system.

\section{Methods}

MPO was isolated from diisopropyl fluorophosphate (Sigma Chemical Co., St. Louis, MO)-treated human neutrophils that were disrupted by nitrogen cavitation (26). The fraction, which contains azurophilic granules, was harvested in Percoll (Pharmacia Fine Chemicals, Piscataway, NJ) gradients as previously described (26), and the contents of this fraction were solubilized in $3 \%$ hexadecyltrimethylammonium bromide (Sigma Chemical Co.) and chromatographed over CM-Sepharose (Pharmacia Fine Chemicals) (applied in $0.1 \mathrm{M}$ ammonium bicarbonate, $\mathrm{pH} 8.0$, and eluted with $0.6 \mathrm{M}\left(\mathrm{NH}_{4}\right) \mathrm{HCO}_{3}, \mathrm{pH} 8.0$ ) and Sephacryl S-200 (Pharmacia Fine Chemicals) (in $0.6 \mathrm{M}\left[\mathrm{NH}_{4}\right] \mathrm{HCO}_{3}$, pH 8.0) in a modification of the method of Andersen et al. (27). The $\mathrm{A}_{\mathbf{4 3 0}} / \mathrm{A}_{\mathbf{2 8 0}}=\mathbf{0 . 8 3}$, and the protein demonstrates characteristic $\alpha$ and $\beta$ dimeric bands of 64,000 and $15,000 \mathrm{~mol}$ wt on $10 \%$ electrophoresed sodium dodecyl sulfate (Bio-Rad Laboratories, Richmond, CA) polyacrylamide gels. The MPO activity, $180-240 \mathrm{U} / \mathrm{mg}$, was defined using 4-aminoantipyrine as a hydrogen donor (28), and was assayed using an absorption coefficient of $89 \mathrm{mM}^{-1} \mathrm{~cm}^{-1}$ at $430 \mathrm{~nm}$ (29). Heatinactivated MPO was heated to $90^{\circ} \mathrm{C}$ for $15 \mathrm{~min}$. Hypochlorous acid was distilled under reduced pressure from a $5.25 \%$ commercial solution (Clorox) that was acidified to $\mathrm{pH} 8(30)$, and assayed at $292 \mathrm{~nm}$ using an absorption coefficient of $391 \mathrm{M}^{-1} \mathrm{~cm}^{-1}$ (31). Solutions of hypobromous acid $(\mathrm{HOBr})$, bromine, and tribromide anion, in equilibrium, were prepared by the addition of $\mathrm{HOCl}$ to buffers that contained excess $\mathrm{Br}^{-}$(32). Due to the instability of these solutions, they were used immediately after their preparation. In the remainder of this report, $\mathrm{HOBr}$ will be used to denote the total concentration of all oxidized bromine species. The bromide concentration of purified human neutrophils, prepared by methods previously described (26), was measured by the formation of gold tribromide in acidic conditions from gold chloride (33). Cells suspended in phosphate-buffered saline (PBS) at a concentration of $8 \times 10^{7} / \mathrm{ml}$ were sonicated at $4^{\circ} \mathrm{C}$ and then centrifuged at $30,000 \mathrm{~g}$ for $30 \mathrm{~min}$. The pellets were again suspended in PBS and were assayed with the $30,000 \mathrm{~g}$ supernatants in duplicate. Calculations were based on a cell volume of $200 \mathrm{cu} \mu \mathrm{m}$ (34). Hydrogen peroxide was diluted from a $30 \%$ stabilized stock solution (superoxol, J. T. Baker, Phillipsburgh, NJ) immediately before an experiment. Stock solutions were assayed iodometrically (35). Deuterium oxide $\left({ }^{2} \mathrm{H}_{2} \mathrm{O}\right)$, which was obtained from J. T. Baker, had an isotopic purity of $99.75 \%$. Histidine was obtained from Sigma Chemical Co. All other inorganic chemicals were reagent grade and water was glass distilled.

Measurement of infrared chemiluminescence. The chemilumines- cence spectrometer has been described in detail previously (22). Spectral analysis was carried out with a set of seven interference filters that were obtained from Pomfret Research Optics Inc., Stamford, CT. The filters had bandwidths of $50 \mathrm{~nm}$ and center wavelengths of 1,070 , $1,170,1,268,1,377,1,475,1,580$ and 1,680 nm. Emission measurements were corrected for the detector response and transmission of each filter. For kinetic experiments, the integral of the emission intensity over the entire reaction period was reported. An estimate of the amount of ' $\mathrm{O}_{2}$ produced was obtained by comparing the emission integral of the system under study with that of the $\mathrm{H}_{2} \mathrm{O}_{2}$ plus $\mathrm{HOBr}$ reaction or the $\mathrm{H}_{2} \mathrm{O}_{2}$ plus $\mathrm{HOCl}$ reaction (24).

MPO systems. The MPO- $\mathrm{H}_{2} \mathrm{O}_{2}$-halide systems were studied at $25^{\circ} \mathrm{C}$. Most experiments were performed in aqueous buffers that contained $98 \%{ }^{2} \mathrm{H}_{2} \mathrm{O}$. In these experiments, the $\mathrm{p}^{2} \mathrm{H}$ was calculated by subtracting 0.4 from the reading obtained with a glass electrode (36). Buffers were $100 \mathrm{mM}$ sodium phosphate $\left(\mathrm{p}^{2} \mathrm{H}, 3,6,7,8\right)$ or $100 \mathrm{mM}$ sodium acetate $\left(p^{2} \mathrm{H}, 4,5\right)$, each containing the desired concentration of $\mathrm{NaCl}$ or $\mathrm{NaBr}$. MPO, in $1.5 \mathrm{ml}$ buffer contained in a dark adapted test tube, was placed in the spectrophotometer. The reaction was initiated by the rapid injection of an additional $1.5 \mathrm{ml}$ of buffer containing $\mathrm{H}_{2} \mathrm{O}_{2}$. For calibration of the ${ }^{1} \mathrm{O}_{2}$ production, $1.5 \mathrm{ml}$ of buffer containing $\mathrm{HOBr}$ or $\mathrm{HOCl}$ was placed in the spectrophotometer and the reaction initiated by the injection of an equal volume of buffer that contained $\mathrm{H}_{2} \mathrm{O}_{2}$.

\section{Results}

Evidence for ${ }^{1} \mathrm{O}_{2}$ production by $\mathrm{MPO}$. Chemiluminescence at $1,268 \mathrm{~nm}$ was detected in the MPO catalyzed oxidation of both $\mathrm{Cl}^{-}$and $\mathrm{Br}^{-}$. Recorder tracings of the time course of the emission under various conditions are shown in Fig. 1. While the intensity of the light with $\mathrm{Br}^{-}$was comparable to that seen with $\mathrm{LPO}$ and $\mathrm{CPO}$, the intensity with $\mathrm{Cl}^{-}$was one to two

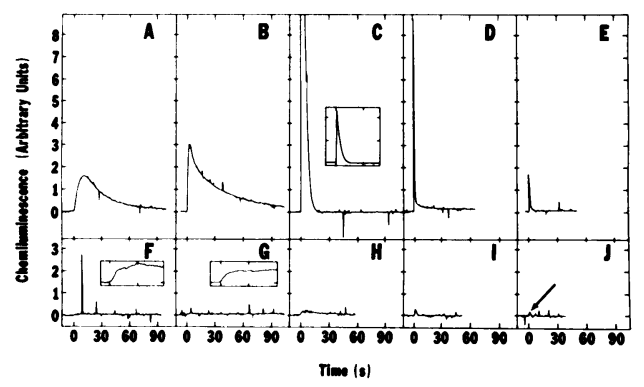

Figure 1. Time course of $1268-\mathrm{nm}$ chemiluminescence in the MPO$\mathrm{H}_{2} \mathrm{O}_{2}$-halide systems. Recordings were made with an amplifier time constant of $0.1 \mathrm{~s}$. All experiments were done in $98 \%{ }^{2} \mathrm{H}_{2} \mathrm{O}$ with 100 mM sodium acetate $\left(p^{2} \mathrm{H} 4,5\right)$ or sodium phosphate $\left(\mathrm{p}^{2} \mathrm{H} 3,6,7\right)$ buffers, $1 \mathrm{mM} \mathrm{H}_{2} \mathrm{O}_{2}$, and $110 \mathrm{nM}$ MPO. Top row had $10 \mathrm{mM}$ $\mathrm{NaBr}$; bottom row had $100 \mathrm{mM} \mathrm{NaCl} . A, \mathrm{p}^{2} \mathrm{H} 3 ; B, \mathrm{p}^{2} \mathrm{H} 4 ; C, \mathrm{p}^{2} \mathrm{H} 5$ (Inset shows signal reduced by a factor of 10 . Time scale and amplifier time constant were unchanged.); $D, \mathrm{p}^{2} \mathrm{H} 6 ; E, \mathrm{p}^{2} \mathrm{H} 7 ; F$, $\mathrm{p}^{2} \mathrm{H} 3$ (Sharp peak was noise spike. The observed signal appeared to be a prolonged shift in the base line shown more clearly in the inset with gain increased by a factor of 10 and the amplifier time constant increased to $10 \mathrm{~s}$.); $G, \mathrm{p}^{2} \mathrm{H} 4$ (inset as in $F$ ); $H, \mathrm{p}^{2} \mathrm{H} 5 ; I, \mathrm{p}^{2} \mathrm{H}$ 6; and $J, \mathrm{p}^{2} \mathrm{H} 7$ 
orders of magnitude lower $(22,24)$. For this reason, most experiments were done in ${ }^{2} \mathrm{H}_{2} \mathrm{O}$, which enhanced the intensity of the light by a factor of 30 , due to the longer half-life of ${ }^{1} \mathrm{O}_{2}$ in ${ }^{2} \mathrm{H}_{2} \mathrm{O}$.

There was substantial evidence to support the assignment of the observed infrared emission to enzymatically generated ${ }^{1} \mathrm{O}_{2}$. As shown in Table $\mathrm{I}$, the emission consisted of a single band with a spectral distribution that was identical to that of ${ }^{1} \mathrm{O}_{2}$. No band was detected at $1,570-1,670 \mathrm{~nm}$ as reported by Khan (37) for CPO and catalase. The emission was inhibited by the ${ }^{1} \mathrm{O}_{2}$ quenchers, histidine, and azide, and was $29 \pm 5$ times greater in ${ }^{2} \mathrm{H}_{2} \mathrm{O}$ than in $\mathrm{H}_{2} \mathrm{O}$ (conditions were pH 5 ,

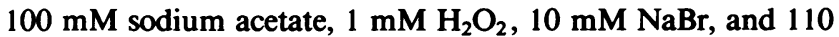
nM MPO). Enzyme activity was required for light production, since no emission was detected with heat-inactivated MPO or with the addition of azide or cyanide (Table II). The observed emission was not due to a reaction between $\mathrm{HOBr}$ and MPO. Replacement of $\mathrm{H}_{2} \mathrm{O}_{2}$ with $\mathrm{HOBr}$ produced only $0.004 \pm 0.001$ as much light (conditions were $\mathrm{p}^{2} \mathrm{H} 5,100 \mathrm{mM}$ sodium acetate, $10 \mathrm{mM} \mathrm{NaBr}, 110 \mathrm{nM} \mathrm{MPO,} 1 \mathrm{mM} \mathrm{H}_{2} \mathrm{O}_{2}$, or $\mathrm{HOBr}$ ).

$\mathrm{MPO}-\mathrm{H}_{2} \mathrm{O}_{2}-\mathrm{Br}^{-}$system: kinetics and ${ }^{1} \mathrm{O}_{2}$ yield. Infrared emission was measured under a variety of conditions to optimize the ${ }^{1} \mathrm{O}_{2}$ production (Tables III and IV, Figs. 2 and $3)$. The mechanism proposed by Allen for ${ }^{1} \mathrm{O}_{2}$ generation by $\mathrm{MPO},\left(\mathrm{H}_{2} \mathrm{O}_{2}+\mathrm{H}^{+}+\mathrm{Br}^{-} \stackrel{\mathrm{MPO}}{\rightarrow} \mathrm{HOBr}+\mathrm{H}_{2} \mathrm{O}\right)\left(\mathrm{H}_{2} \mathrm{O}_{2}+\mathrm{HOBr} \rightarrow\right.$ $\left.\mathrm{H}_{2} \mathrm{O}+\mathrm{H}^{+}+\mathrm{Br}^{-}+{ }^{1} \mathrm{O}_{2}\left({ }^{1} \Delta_{\mathrm{g}}\right)\right)$, predicts that $1 \mathrm{~mol}$ of ${ }^{1} \mathrm{O}_{2}$ will be produced for each $2 \mathrm{~mol}$ of $\mathrm{H}_{2} \mathrm{O}_{2}$ consumed (13). The chemiluminescence integral under optimal conditions $\left(\mathrm{H}_{2} \mathrm{O}\right.$ solvent, pH 5, $100 \mathrm{mM}$ sodium acetate, $100 \mathrm{mM} \mathrm{NaBr}, 1$ $\mathrm{mM} \mathrm{H}_{2} \mathrm{O}_{2}$, and $430 \mathrm{nM} \mathrm{MPO)} \mathrm{was} \mathrm{compared} \mathrm{with} \mathrm{the}$

Table I. Spectral Analysis of the Infrared Chemiluminescence in the MPO- $\mathrm{H}_{2} \mathrm{O}_{2}$-Halide Systems Compared to that of Singlet Oxygen Produced in the $\mathrm{H}_{2} \mathrm{O}_{2}$ Plus $\mathrm{HOCl}$ Reaction

\begin{tabular}{|c|c|c|c|}
\hline \multirow[b]{3}{*}{ Filter } & \multicolumn{3}{|c|}{ Chemiluminescence* } \\
\hline & \multicolumn{2}{|l|}{ MPO } & \multirow[b]{2}{*}{$\mathrm{H}_{2} \mathrm{O}_{2}+\mathrm{HOCl}$} \\
\hline & Bromide† & Chloride§ & \\
\hline \multicolumn{4}{|l|}{$n m$} \\
\hline 1,070 & $-0.002 \pm 0.001$ & $0.02 \pm 0.01$ & $0.000 \pm 0.002$ \\
\hline 1,170 & $-0.001 \pm 0.001$ & $0.01 \pm 0.01$ & $0.003 \pm 0.003$ \\
\hline 1,268 & $1.00 \pm 0.01$ & $1.00 \pm 0.02$ & $1.00 \pm 0.02$ \\
\hline 1,377 & $0.77 \pm 0.01$ & $0.66 \pm 0.03$ & $0.59 \pm 0.01$ \\
\hline 1,475 & $0.12 \pm 0.003$ & $0.16 \pm 0.04$ & $0.14 \pm 0.02$ \\
\hline 1,580 & $0.014 \pm 0.004$ & $0.01 \pm 0.02$ & $0.03 \pm 0.004$ \\
\hline 1,680 & $-0.001 \pm 0.003$ & $0.02 \pm 0.02$ & $0.014 \pm 0.002$ \\
\hline
\end{tabular}

- Each system was normalized so that the emission through the 1,268-nm filter was 1.00 .

$\ddagger 98 \%{ }^{2} \mathrm{H}_{2} \mathrm{O}, \mathrm{p}^{2} \mathrm{H} 5,100 \mathrm{mM}$ sodium acetate, $10 \mathrm{mM} \mathrm{NaBr}, 1 \mathrm{mM} \mathrm{H}_{2} \mathrm{O}_{2}$, and $44 \mathrm{nM}$ MPO.

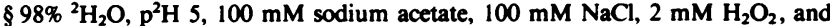
74 nM MPO.

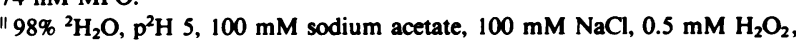
and $0.5 \mathrm{mM} \mathrm{HOCl}$.
Table II. Effect of Enzyme Inhibitors and ${ }^{\prime} \mathrm{O}_{2}$ Quenchers on 1,268-nm Chemiluminescence in the MPO- $\mathrm{H}_{2} \mathrm{O}_{2}-\mathrm{Br}^{-}$System

\begin{tabular}{lc}
\hline Sample* & Relative chemiluminescence \\
\hline Control & $1.0 \pm 0.1$ \\
Heat-inactivated enzyme & $0.00 \pm 0.01$ \\
$1.5 \mathrm{mM} \mathrm{KCN}^{*} \mathrm{mM} \mathrm{NaN}_{3}$ & $0.00 \pm 0.01$ \\
$1.5 \mathrm{mM}$ histidine & $-0.01 \pm 0.01$ \\
$1.5 \mathrm{mM}^{*}$ & $0.04 \pm 0.01$
\end{tabular}

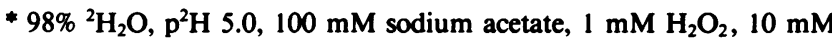
$\mathrm{NaBr}$, and $48 \mathrm{nM} \mathrm{MPO}$.

emission integral of the $\mathrm{H}_{2} \mathrm{O}_{2}$ plus $\mathrm{HOBr}$ reaction. The validity and limitations of this calibration procedure have been the subject of a past study (24). The MPO- $\mathrm{H}_{2} \mathrm{O}_{2}-\mathrm{Br}^{-}$system produced $83 \pm 5 \%$ of the chemiluminescence that was predicted by the Allen mechanism.

As shown in Fig. 1 and Table III, the emission integral decreased at $\mathrm{p}^{2} \mathrm{H}>5$. In Fig. $1 \mathrm{D}$, the emission was of high intensity but short duration, which suggests that enzyme inactivation was a major factor limiting the yield of ${ }^{1} \mathrm{O}_{2}$. Consistent with this hypothesis was the fact that the injection of a second aliquot of enzyme produced a second emission spike. Also, as seen in Tables III and IV, the chemiluminescence integral $/\left(\mathrm{H}_{2} \mathrm{O}_{2}\right)$ was increased by raising the enzyme concentration or by lowering the $\mathrm{H}_{2} \mathrm{O}_{2}$ concentration. Higher $\mathrm{NaBr}$ concentrations also favored more efficient production of ${ }^{1} \mathrm{O}_{2}$ at higher $\mathrm{p}^{2} \mathrm{H}$.

Bromide was quantitated in sonicated neutrophils to determine the physiologic availability of this halide. Free bromide (that is, the concentration in the cell $-30,000$-g pellet) was undetectable, while that associated with the $30,000 \mathrm{~g}$ precipitable constituents was $6.6 \pm 2.2 \mathrm{mM}$ (mean $\pm \mathrm{SD}, n=4$ ). Presumably the $\mathrm{Br}^{-}$associated with proteins is not available for MPOcatalyzed oxidations, but its function in this system could not be further characterized due to limitation of $1268-\mathrm{nm}$ chemiluminescence sensitivity.

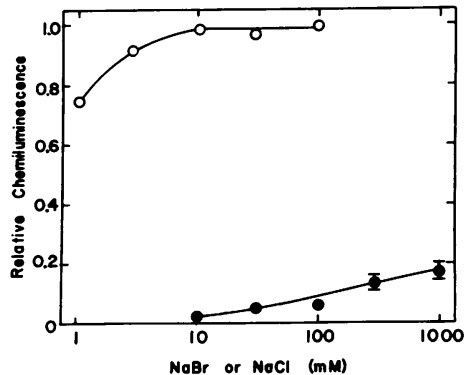

Figure 2. Effect of halide concentration on 1268-nm emission in the MPO$\mathrm{H}_{2} \mathrm{O}_{2}-\mathrm{Cl}^{-}$and $\mathrm{MPO}-\mathrm{H}_{2} \mathrm{O}_{2-}$ $\mathrm{Br}^{-}$systems. Conditions were $98 \%{ }^{2} \mathrm{H}_{2} \mathrm{O}, \mathrm{p}^{2} \mathrm{H} 5,100$ $\mathrm{mM}$ sodium acetate, and 1 $\mathrm{mM} \mathrm{H}_{2} \mathrm{O}_{2}$. Enzyme concentrations were $44 \mathrm{nM}$ for the MPO- $\mathrm{H}_{2} \mathrm{O}_{2}-\mathrm{Br}^{-}$system

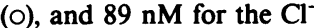
system (๑). Emission inte-

grals in both systems were normalized to the maximum value seen in the MPO- $\mathrm{H}_{2} \mathrm{O}_{2}-\mathrm{Br}^{-}$system. Error bars are not shown when the SEM is less than the size of the symbol. 




Figure 3. Effect of $\mathrm{H}_{2} \mathrm{O}_{2}$ concentration on the $1268-\mathrm{nm}$ emission in the $\mathrm{Cl}^{-}$and the MPO- $\mathrm{H}_{2} \mathrm{O}_{2}-\mathrm{Br}^{-}$systems. Conditions were $98 \%{ }^{2} \mathrm{H}_{2} \mathrm{O}, p^{2} \mathrm{H} 5$, and $100 \mathrm{mM}$ sodium acetate. O, MPO- $\mathrm{H}_{2} \mathrm{O}_{2}-\mathrm{Br}^{-}$system, 44 nM MPO, and $10 \mathrm{mM} \mathrm{NaBr}$; •, $\mathrm{Cl}^{-}$system, $89 \mathrm{nM} \mathrm{MPO}$, and $100 \mathrm{mM} \mathrm{NaCl}$. The size of the symbol indicates the SEM.

$\mathrm{Cl}^{-}$system, kinetics, and ${ }^{\prime} \mathrm{O}_{2}$ yield. For the conditions studied, ${ }^{1} \mathrm{O}_{2}$ production by the $\mathrm{Cl}^{-}$system was always inefficient. As shown in Table III, the maximum emission integral occurred at $p^{2} \mathrm{H} 4$ with $5 \mathrm{mM} \mathrm{H}_{2} \mathrm{O}_{2}$. Unfortunately, any chemiluminescence produced at $\mathrm{H}_{2} \mathrm{O}_{2}$ concentrations of $0.25 \mathrm{mM}$ or less was below the detection limit of the spectrophotometer, so efficient production of ${ }^{1} \mathrm{O}_{2}$ at these low $\mathrm{H}_{2} \mathrm{O}_{2}$ concentrations cannot be excluded.

Enzyme inactivation was a major factor limiting the yield of ${ }^{1} \mathrm{O}_{2}$. At $p^{2} \mathrm{H} 6$ and 7 , the emission was of short duration, similar to the MPO- $\mathrm{H}_{2} \mathrm{O}_{2}-\mathrm{Br}^{-}$system. Injection of a second aliquot of enzyme produced a second light spike. The behavior of the system was complex, however, since the emission integral did not increase with increasing enzyme concentrations.

At $p^{2} \mathrm{H} 3$ and 4 , the emission was of low intensity and long duration, consistent with low enzyme activity, which resisted rapid inactivation. The intensity was not limited by the rate of the $\mathrm{H}_{2} \mathrm{O}_{2}$ plus $\mathrm{HOCl}$ reaction, since the emission intensity of this reaction $\left(0.5 \mathrm{mM} \mathrm{H}_{2} \mathrm{O}_{2}\right.$ plus $\left.0.5 \mathrm{mM} \mathrm{HOCl}\right)$ was one to two orders of magnitude higher than that seen with MPO ( $1 \mathrm{mM} \mathrm{H}_{2} \mathrm{O}_{2}$, data not shown). The kinetic behavior of the system under these conditions is complex. As seen in Fig. 4 , the onset of the emission was delayed by several seconds.
The addition of a second aliquot of enzyme during the period of prolonged light production abolished the emission for several seconds, which was followed by the return of chemiluminescence of lower intensity.

\section{Discussion}

The putative role of singlet oxygen in the respiratory burst of the human neutrophil has remained elusive due to the inability to reliably assess its quantitative production (2). Previous attempts to trace its generation by traps and quenchers have been discredited on the basis of the nonspecificity of the reactive profile (15-18). Chemiluminescence in the visible spectrum is both nonspecific and relatively insensitive. A previous study measuring radioactive cholesterol derivatives concluded that ${ }^{1} \mathrm{O}_{2}$, if produced at all, was a quantitatively insignificant product of the respiratory burst (19). In this study, we have examined chemiluminescence at 1,268 $\mathrm{nm}$, a characteristic emission band of ${ }^{1} \mathrm{O}_{2}$, of a purified human MPO system to define the conditions and quantity of ${ }^{1} \mathrm{O}_{2}$ production. The validity and limitations of this method have been discussed previously (25). With the use of the purified MPO systems, we have determined conditions under which ${ }^{1} \mathrm{O}_{2}$ is generated, and that only at low acid pH with high $\mathrm{H}_{2} \mathrm{O}_{2}$ concentrations or at high bromide ion concentrations is this reaction favored.

The role of a $\mathrm{Br}^{-}$-dependent MPO mechanism for ${ }^{1} \mathrm{O}_{2}$ production in stimulated neutrophils remains to be elucidated. The concentrations of free $\mathrm{Br}^{-}$required for ${ }^{1} \mathrm{O}_{2}$ production are not found in the neutrophil (our results), and make this pathway a problematic source for ${ }^{1} \mathrm{O}_{2}$ production. (The $\mathrm{Br}^{-}$ associated with the $30,000-\mathrm{g}$ neutrophil particulate fraction is $\sim 60$-fold greater than in whole blood (38), but it remains unassigned to a particular compartment or protein.) Because of technical limitations of signal to noise ratios, we have thus far been unable to confirm $1,268-\mathrm{nm}$ chemiluminescence in stimulated neutrophils arising from the $\mathrm{MPO}-\mathrm{Br}^{-}$system. The

Table III. Effect of $p^{2} \mathrm{H}$ on 1268-nm Chemiluminescence in the $\mathrm{MPO}-\mathrm{H}_{2} \mathrm{O}_{2}-\mathrm{Br}^{-}$and $\mathrm{MPO}-\mathrm{H}_{2} \mathrm{O}_{2}-\mathrm{Cl}^{-}$Systems

\begin{tabular}{|c|c|c|c|c|c|c|c|}
\hline \multicolumn{2}{|l|}{$p^{2} \mathbf{H}$} & \multirow[b]{2}{*}{ (Chemilumi } & 4 & \multirow[t]{2}{*}{5} & \multirow[t]{2}{*}{6} & \multirow[t]{2}{*}{7} & \multirow[t]{2}{*}{8} \\
\hline $\mathrm{H}_{2} \mathrm{O}_{2}$ & Halide & & ntegral) $/ \mathrm{H}_{2} \mathrm{O}_{2}{ }^{*}$ & & & & \\
\hline$m M$ & $m M$ & & & & & & \\
\hline 1 & $10, \mathrm{NaBr}$ & $0.53 \pm 0.01$ & $0.90 \pm 0.05$ & $0.91 \pm 0.03$ & $0.14 \pm 0.004$ & $0.026 \pm 0.001$ & $0.001 \pm 0.001$ \\
\hline 0.1 & $10, \mathrm{NaBr}$ & & $0.84 \pm 0.08$ & $0.60 \pm 0.02$ & $0.63 \pm 0.03$ & $0.31 \pm 0.01$ & $0.00 \pm 0.01$ \\
\hline 1 & $100, \mathrm{NaBr}$ & & & $1.00 \pm 0.01$ & $0.24 \pm 0.01$ & $0.04 \pm 0.002$ & $0.004 \pm 0.001$ \\
\hline 0.1 & $100, \mathrm{NaBr}$ & & & & $0.96 \pm 0.02$ & $0.76 \pm 0.05$ & $0.02 \pm 0.01$ \\
\hline 10 & $100, \mathrm{NaCl}$ & & $0.10 \pm 0.01$ & & & & \\
\hline 5 & $100, \mathrm{NaCl}$ & & $0.22 \pm 0.05$ & & & & \\
\hline 1 & $100, \mathrm{NaCl}$ & $0.12 \pm 0.02 \ddagger$ & $0.09 \pm 0.03 \ddagger$ & $0.04 \pm 0.005$ & $0.014 \pm 0.003$ & $0.001 \pm 0.0004$ & $-0.000 \pm 0.002$ \\
\hline
\end{tabular}

* The emission integral is expressed as a fraction of that seen in the MPO- $\mathrm{H}_{2} \mathrm{O}_{2}-\mathrm{Br}^{-}$system at $\mathrm{p}^{2} \mathrm{H} 5,1 \mathrm{mM} \mathrm{H}_{2} \mathrm{O}_{2}$, and $100 \mathrm{mM} \mathrm{NaBr}$. The $\mathrm{MPO}$ concentration was $110 \mathrm{nM}$. Experiemnts were done in $98 \%{ }^{2} \mathrm{H}_{2} \mathrm{O}$ with $100 \mathrm{mM}$ sodium acetate $\left(\mathrm{p}^{2} \mathrm{H} 4,5\right)$ or $100 \mathrm{mM}$ sodium phosphate $\left(\mathrm{p}^{3} \mathrm{H} 3,6,7,8\right)$. $\ddagger$ Estimated from the peak intensity and half-life of the chemiluminescence. 
Table IV. Effect of Enzyme Concentration on the 1268-nm Chemiluminescence in the $\mathrm{MPO}-\mathrm{H}_{2} \mathrm{O}_{2}-\mathrm{Br}^{-}$ and the $\mathrm{Cl}^{-}$Systems

\begin{tabular}{|c|c|c|c|c|}
\hline \multirow[b]{3}{*}{ MPO } & \multicolumn{4}{|c|}{ Chemiluminescence integral ${ }^{*}$} \\
\hline & \multicolumn{2}{|c|}{ MPO- $\mathrm{H}_{2} \mathrm{O}_{2}-\mathrm{Br}^{-} \ddagger$} & \multicolumn{2}{|l|}{$\mathrm{Cl}^{-} \S$} \\
\hline & $\mathrm{p}^{2} \mathrm{H} 5$ & $p^{2} \mathrm{H} 6$ & $\mathrm{p}^{2} \mathrm{H} 5$ & $\mathrm{p}^{2} \mathrm{H} 6$ \\
\hline \multicolumn{5}{|l|}{$n M$} \\
\hline 11 & $0.87 \pm 0.02$ & & & \\
\hline 22 & $0.96 \pm 0.01$ & & $0.12 \pm 0.01$ & \\
\hline 44 & $1.00 \pm 0.01$ & $0.018 \pm 0.001$ & $0.11 \pm 0.003$ & \\
\hline 89 & & $0.037 \pm 0.003$ & $0.07 \pm 0.01$ & $0.003 \pm 0.001$ \\
\hline 180 & & $0.084 \pm 0.003$ & & $0.004 \pm 0.001$ \\
\hline 370 & & & & $0.005 \pm 0.001$ \\
\hline
\end{tabular}

* $98 \%{ }^{2} \mathrm{H}_{2} \mathrm{O}, 100 \mathrm{mM}$ sodium acetate, $\mathrm{p}^{2} \mathrm{H} 5$, or $100 \mathrm{mM}$ sodium phosphate, $\mathrm{p}^{2} \mathrm{H} \mathrm{6}$, and $1 \mathrm{mM} \mathrm{H}_{2} \mathrm{O}_{2}$. The integral is expressed as a fraction of the emission integral of the $\mathrm{MPO}-\mathrm{H}_{2} \mathrm{O}_{2}-\mathrm{Br}^{-}$system at $\mathrm{p}^{2} \mathrm{H} 5$ and $44 \mathrm{nM}$ enzyme.

$\$ 10 \mathrm{mM} \mathrm{NaBr}$.

$\S 100 \mathrm{mM} \mathrm{NaCl}$.

low $\mathrm{pH}$ at which $\mathrm{Cl}^{-}$might efficiently serve as the halide source is not attained, even in the phagocytic vacuole, in the same time course as the chemiluminescent response of the phagocytosing neutrophil $(20,39-41)$; this $\mathrm{Cl}^{-}$pathway then is an unlikely source for ${ }^{1} \mathrm{O}_{2}$ in stimulated neutrophils.

The MPO- $\mathrm{H}_{2} \mathrm{O}_{2}-\mathrm{Br}^{-}$system produced ${ }^{1} \mathrm{O}_{2}$ in near stoichiometric yield, which is similar to the behavior of LPO and CPO $(24,25)$. However, in contrast to CPO, which also efficiently produced ${ }^{1} \mathrm{O}_{2}$ with $\mathrm{Cl}^{-}$as a substrate, the production of ${ }^{1} \mathrm{O}_{2}$ by the $\mathrm{Cl}^{-}$system was always inefficient (24). Enzyme inactivation by $\mathrm{HOCl}$ or chlorine $\left(\mathrm{Cl}_{2}\right)$ was a major factor limiting the yield of ${ }^{1} \mathrm{O}_{2}$. As previously described in studies of MPO kinetics (42), the inactivation process is complex and depends

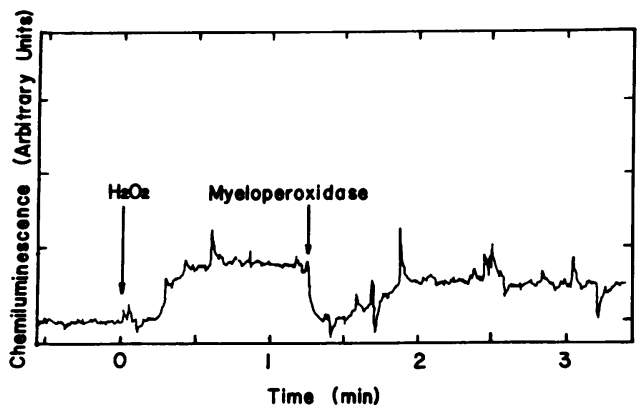

Figure 4. The disappearance of $1268-\mathrm{nm}$ chemiluminescence in the $\mathrm{Cl}^{-}$system caused by the addition of fresh MPO. Conditions were $98 \%{ }^{2} \mathrm{H}_{2} \mathrm{O}, \mathrm{p}^{2} \mathrm{H} 4,100 \mathrm{mM}$ sodium acetate, $100 \mathrm{mM} \mathrm{NaCl}, 1 \mathrm{mM}$ $\mathrm{H}_{2} \mathrm{O}_{2}$, and $89 \mathrm{nM}$ MPO. $1 \mathrm{ml}$ of buffer that contained MPO was placed in the spectrometer. The reaction was initiated by the injection of $1 \mathrm{ml}$ of buffer that contained $\mathrm{H}_{2} \mathrm{O}_{2}$. Then an additional $1 \mathrm{ml}$ of buffer that contained MPO was added. The amplifier time constant was $1 \mathrm{~s}$. on the product of the $\mathrm{H}^{+}$concentration $\left(\mathrm{H}^{+}\right)$and the $\mathrm{Cl}^{-}$ concentration, $\left(\mathrm{Cl}^{-}\right)$. A high $\left(\mathrm{H}^{+}\right)\left(\mathrm{Cl}^{-}\right)$product reduces the $\mathrm{HOCl}$ concentration to which the MPO is exposed for three reasons. First, as demonstrated by Andrews and Krinsky (43), a high $\left(\mathrm{H}^{+}\right)\left(\mathrm{Cl}^{-}\right)$product will inhibit the MPO activity by raising the $K_{\mathrm{m}}$ for $\mathrm{H}_{2} \mathrm{O}_{2}$. This accounts, in part, for the low intensity of the emission under these conditions, since the enzymatic oxidation of $\mathrm{Cl}^{-}$is the rate limiting step in the ${ }^{1} \mathrm{O}_{2}$ production. Second, the rate of the $\mathrm{H}_{2} \mathrm{O}_{2}$ plus $\mathrm{HOCl}$ reaction is proportional to the $\left(\mathrm{H}^{+}\right)\left(\mathrm{Cl}^{-}\right)$product and consequently limits the accumulation of $\mathrm{HOCl}(30)$. Finally, a high $\left(\mathrm{H}^{+}\right)$ $\left(\mathrm{Cl}^{-}\right)$product shifts the equilibrium between $\mathrm{HOCl}$ and $\mathrm{Cl}_{2}$ toward $\mathrm{Cl}_{2}$ (32). The reaction of $\mathrm{Cl}_{2}$ with $\mathrm{MPO}$ may be less destructive than $\mathrm{HOCl}$.

In our studies, when the $\left(\mathrm{H}^{+}\right)\left(\mathrm{Cl}^{-}\right)$product was low, for example at $\mathrm{pH} 6$ and $100 \mathrm{mM} \mathrm{Cl}^{-}$, there was rapid and complete enzyme inactivation and the chemiluminescence was of short duration. Lowering the $\mathrm{pH}$ or raising the $\mathrm{NaCl}$ concentration at $\mathrm{pH} 5$ resulted in prolonged low level emission (data not shown for high $\mathrm{NaCl}$ concentrations). Under these conditions, the onset of the emission was delayed and the light production was temporarily inhibited by the addition of fresh enzyme. One explanation for these observations is that the initial $\mathrm{HOCl}$ produced is consumed by highly reactive functional groups on the MPO. When these groups are fully saturated, a partially inactivated enzyme continues to make $\mathrm{HOCl}$ which reacts with $\mathrm{H}_{2} \mathrm{O}_{2}$ to produce ${ }^{1} \mathrm{O}_{2}$. In the $\mathrm{MPO}-\mathrm{H}_{2} \mathrm{O}_{2}-\mathrm{Br}^{-}$ system, enzyme inactivation is less significant. To some degree, this is due to the fact that $\mathrm{HOBr}$ is a weaker oxidizing agent than $\mathrm{HOCl}$. The extremely rapid rate of the $\mathrm{H}_{2} \mathrm{O}_{2}$ plus $\mathrm{HOBr}$ reaction compared to the $\mathrm{H}_{2} \mathrm{O}_{2}$ plus $\mathrm{HOCl}$ reaction may be a more important factor, however, since this limits the $\mathrm{HOBr}$ concentration to a small fraction of the $\mathrm{HOCl}$ concentration in these systems $(30,44)$.

Based on pH and halide requirements of ${ }^{1} \mathrm{O}_{2}$ production by purified MPO, it is unlikely that ${ }^{1} \mathrm{O}_{2}$ is generated physiologically in the respiratory burst through a MPO mechanism. Although MPO is a potential source of ${ }^{1} \mathrm{O}_{2}$, its production optimally occurs at nonphysiologic $\mathrm{pH}$ with nonphysiologic concentrations of free bromide. Compared to the $\mathrm{MPO}-\mathrm{H}_{2} \mathrm{O}_{2}$ $\mathrm{Br}^{-}$system, the $\mathrm{Cl}^{-}$system is a poor source of ${ }^{1} \mathrm{O}_{2}$, largely because of the much more rapid rate of the $\mathrm{H}_{2} \mathrm{O}_{2}$ plus $\mathrm{HOBr}$ reaction relative to the $\mathrm{H}_{2} \mathrm{O}_{2}$ plus $\mathrm{HOCl}$ reaction. This difference in reaction rates is likely to be even more important in the intact neutrophil, where the hypohalous acid can react with a high concentration of biomolecules $(6,7,15,45)$. Based on these studies, the physiologic production of ${ }^{1} \mathrm{O}_{2}$ by an MPOmediated system appears unlikely.

\section{Acknowledgments}

We wish to thank William Wardman for technical assistance in performing experiments and Ms. Ann Marie Spry for secretarial assistance. 
This work is supported by grants GM-32974, AI-20064, and 5SO7RR05368 from the National Institutes of Health, the Veterans Administration Research Service, Hoffman-La Roche, Inc., The Neutrophil Research Fund, Inc., and an intramural research support grant from Loyola University.

\section{References}

1. Babior, B. M. 1978. Oxygen-dependent microbial killing by phagocytes. N. Engl. J. Med. 298:659-668, 721-725.

2. Badwey, J. A., and M. L. Karnovsky. 1980. Active oxygen species and the functions of phagocytic leukocytes. Annu. Rev. Biochem. 49:695-726.

3. Tauber, A. I., N. Borregaard, E. Simons, and J. Wright. 1983. Chronic granulomatous disease: a syndrome of phagocyte oxidase deficiencies. Medicine (Balt.). 62:286-309.

4. Klebanoff, S. J. 1980. Cytocidal mechanisms of phagocytic cells. In Immunology 80, Vol. 2, Progress Immunology IV. M. Fougereau and J. Daussey, editors. Academic Press, London. 720-736.

5. Clark, R. A. 1983. Extracellular effects of the myeloperoxidasehydrogen peroxide-halide system. Adv. Inflammation Res. 5:107-146.

6. Thomas, E. L. 1979. Myeloperoxidase, hydrogen peroxide, chloride antimicrobial system: nitrogen-chlorine derivatives of bacterial components in bactericidal action against Escherichia coli. Infect. Immun. 23:522-531.

7. Weiss, S. J., R. Klein, A. Slivka, and M. Wei. 1982. Chlorination of taurine by human neutrophils. Evidence for hypochlorous acid generation. J. Clin. Invest. 70:598-607.

8. Foote, C. S., T. E. Goyne, and R. I. Lehrer. 1983. Assessment of chlorination by human neutrophils. Nature (Lond.). 301:715-718.

9. Harrison, J. E., and J. Schultz. 1976. Studies on the chlorinating activity of myeloperoxidase. J. Biol. Chem. 251:1371-1374.

10. Allen, R. C., R. L. Stjernholm, and R. H. Steele. 1972. Evidence for the generation of an electronic excitation state(s) in human polymorphonuclear leukocytes and its participation in bactericidal activity. Biochem. Biophys. Res. Commun. 47:679-684.

11. Krinsky, N. I. 1974. Singlet excited oxygen as a mediator of the antibacterial action of leukocytes. Science (Wash. DC). 186:363365.

12. Johnston, R. B., and J. E. Lehmeyer. 1977. The involvement of oxygen metabolites from phagocytic cells in bactericidal activity and inflammation. In Superoxide and Superoxide Dismutases. A. M. Michelson, J. M. McCord, and I. Fridovich, editors. Academic Press, London. 291-304.

13. Allen, R. C. 1975 . Halide dependence of the myeloperoxidasemediated antimicrobial system of the polymorphonuclear leukocyte in the phenomenon of electronic excitation. Biochem. Biophys. Res. Commun. 63:675-683.

14. Rosen, H., and S. J. Klebanoff. 1977. Formation of singlet oxygen by the myeloperoxidase-mediated antimicrobial system. J. Biol. Chem. 252:4803-4810.

15. Held, A. M., and J. K. Hurst. 1978. Ambiguity associated with use of singlet oxygen trapping agents in myeloperoxidase-catalyzed oxidations. Biochem. Biophys. Res. Commun. 81:878-885.

16. Harrison, J. E., B. D. Watson, and J. Schultz. 1978. Myeloperoxidase and singlet oxygen: a reappraisal. FEBS (Fed. Eur. Biochem. Soc.) Lett. 92:327-332.

17. Foote, C. S. 1979. Detection of singlet oxygen in complex systems: a critique. In Biochemical and Clinical Aspects of Oxygen. W. S. Caughley, editor. Academic Press, Inc., New York. 603-626.

18. Takayama, K., T. Noguchi, M. Nakano, and T. Migita. 1977. Reactivities of diphenylfuran (a singlet oxygen trap) with singlet oxygen and hydroxyl radical in aqueous systems. Biochem. Biophys. Res. Commun. 75:1052-1058.

19. Foote, C. S., R. B. Abakerli, R. L. Clough, and R. I. Lehrer. 1981. On the question of singlet oxygen production in polymorphonuclear leukocytes. In Bioluminescence and Chemiluminescence. M. A. DeLuca and W. D. McElroy, editors. Academic Press, Inc., New York. 81-88.

20. Cheson, B. D., R. S. Christensen, R. Sperling, B. E. Koehler, and B. M. Babior. 1976. The origin of the chemiluminescence of phagocytosing granulocytes. J. Clin. Invest. 58:789-796.

21. Browne, R. J., and E. A. Ogryzlo. 1965. The yield of singlet oxygen in the reaction of chlorine with hydrogen peroxide. Can. J. Chem. 43:2915-2916.

22. Kanofsky, J. R. 1983. Singlet oxygen production by lactoperoxidase, evidence from $1270 \mathrm{~nm}$ chemiluminescence. J. Biol. Chem. 258:5991-5993.

23. Khan, A. U., P. Gebauer, and L. P. Hager. 1983. Chloroperoxidase generation of singlet $\Delta$ molecular oxygen observed directly by spectroscopy in the 1- to $1.6-\mu \mathrm{m}$ region. Proc. Natl. Acad. Sci. USA. 80:5195-5197.

24. Kanofsky, J. R. 1984. Singlet oxygen production by chloroperoxidase-hydrogen peroxide-halide systems. J. Biol. Chem. 259:55965600.

25. Kanofsky, J. R. 1984. Singlet oxygen production by lactoperoxidase: halide dependence and quantitation of yield. J. Photochem. 25:105-113.

26. Borregaard, N., and A. I. Tauber. 1984. Subcellular localization of the human neutrophil NADPH-oxidase: $b$ cytochrome and associated flavoprotein. J. Biol. Chem. 259:47-52.

27. Andersen, M. R., C. L. Atkin, and H. J. Eyre. 1982. Intact form of myeloperoxidase from normal human neutrophils. Arch. Biochem. Biophys. 214:273-283.

28. Matheson, N. R., P. S. Wong, and J. Travis. 1981. Isolation and properties of human neutrophil myeloperoxidase. Biochemistry. 20:325-330.

29. Bakkenist, A. R. J., R. Wever, T. Vulsma, H. Plat, and B. F. Van Gelder. 1978. Isolation procedure and some properties of myeloperoxidase from human leukocytes. Biochim. Biophys. Acta. 524:4554.

30. Held, A. M., D. J. Halko, and J. K. Hurst. 1978. Mechanisms of chlorine oxidation of hydrogen peroxide. J. Am. Chem. Soc. 100:5732-5740.

31. Chen, T. 1967. Spectrophotometric determination of microquantities of chlorate, chlorite, hypochlorite, and chloride in perchlorate. Anal. Chem. 39:804-813.

32. Downs, A. J., and C. J. Adams. 1973. Chlorine, bromine, iodine, and astatine. In Comprehensive Inorganic Chemistry. J. C. Bailar, Jr., H. J. Emeléus, R. Nyholm, and A. F. Trotman-Dickenson, editors. Pergamon Press, Oxford. 1190-1192.

33. Blanker, R. V. 1976. Analysis of toxic drugs and substances. In Fundamentals of Clinical Chemistry. N. Tietz, editor. W. B. Saunders Co., Philadelphia. Second ed. 1128-1129.

34. Schmid-Schönbein, G. W., Y. Y. Shih, and S. Chien. 1980. Morphometry of human leukocytes. Blood. 56:866-875.

35. Cotton, M. L., and H. B. Dunford. 1973. Studies on horseradish peroxidase. XI. On the nature of compounds I and II as determined 
from the kinetics of the oxidation of ferrocyanide. Can. J. Chem. 51:582-587.

36. Salomaa, P., L. L. Schaleger, and F. A. Long. 1964. Solvent deuterium isotope effects on acid-base equilibria. J. Am. Chem. Soc. 86:1-7.

37. Khan, A. U. 1983. Enzyme systems generation of singlet $\left({ }^{1} \Delta_{q}\right)$ molecular oxygen observed directly by $1.0-1.8-\mu \mathrm{m}$ luminescence spectroscopy. J. Am. Chem. Soc. 105:7195-7197.

38. Holzbecher, J., and D. E. Ryan. 1980. The rapid determination of total bromine and iodine in biological fluids by neutron activation. Clin. Biochem. 13:277-278.

39. Cech, P., and R. I. Lehrer. 1984. Phagolysosomal pH of human neutrophils. Blood. 63:88-95.

40. Jacques, Y. V., and D. F. Bainton. 1978. Changes in pH within the phagocytic vacuoles of human neutrophils and monocytes. Lab. Invest. 39:179-185.
41. Cheung, K., A. C. Archibald, and M. F. Robinson. 1983. The origin of chemiluminescence produced by neutrophils stimulated by opsonized zymosan. J. Immunol. 130:2324-2329.

42. Naskalski, J. W. 1977. Myeloperoxidase inactivation in the course of catalysis of chlorination of taurine. Biochim. Biophys. Acta. 485:291-300.

43. Andrews, P. C., and N. I. Krinsky. 1982. A kinetic analysis of the interaction of human myeloperoxidase with hydrogen peroxide, chloride ions and protons. J. Biol. Chem. 257:13240-13245.

44. Bray, W. C., and R. S. Livingston. 1928. The rate of oxidation of hydrogen peroxide by bromine and its relation to the catalytic decomposition of hydrogen peroxide in a bromine-bromide solution. J. Am. Chem. Soc. 50:1654-1665.

45. Thomas, E. L., M. B. Grisham, and M. M. Jefferson. 1983. Myeloperoxidase-dependent effect of amines on functions of isolated neutrophils. J. Clin. Invest. 72:441-454. 